\title{
Dynamics of Nonlinear Processes of Corrosion of Non-Nikel Titanium Shape Memory Alloy
}

\author{
A. G. Kolmakov, E. O. Nasakina, ${ }^{*}$ M. A. Sevostyanov, S. V. Konushkin, and K. V. Sergiyenko \\ A. A. Baikov Institute of Metallurgy and Material Science of the Russian Academy of Sciences, Moscow, RUSSIA

\begin{abstract}
M. L. Kheifetz ${ }^{\dagger}$
Open Joint Stock Company "NPO Center" National Academy of Sciences of Belarus, Minsk, BELARUS
\end{abstract}

(Received 10 October, 2019)

\begin{abstract}
Research of dynamics of nonlinear corrosion processes of non-nickel titanium shape memory alloy Ti-20Nb-10Ta is performed. Samples were placed in mediums imitating physiological liquids, with $\mathrm{pH}$ from 1.68 to 9.18 . 3 types of samples were used: in an initial state, after thermal (annealing) and surface mechanical treatment. After annealing, there is a slight narrowing of the X-ray peaks, which indicates stress relief. New phases are not allocated. The alloy is a substitution solution with a b-Ti lattice. The greatest release of titanium ions was observed in solution with the sourest environment and samples after annealing. Release of niobium and tantalum ions in solution with any acidity was not observed.
\end{abstract}

PACS numbers: 05.45.Df; 79.60.Jv; 81.07.Wx; 81.16.-c

Keywords: titanium, shape memory alloy, tantalum, niobium, corrosion resistance, depassivating action, pitting formation

DOI: https://doi.org/10.33581/1561-4085-2019-22-4-354-361

\section{Introduction}

The shape memory alloys have mechanical properties similar to those of living tissues superelasticity and compliance with the delay law, which led to their use in medicine.

TiNi is the most famous and well-established of them [1-2]. But its possible release of toxic nickel ions, relatively low radiopacity, corrosion resistance, biological and histological compatibility, etc. question its medical use [315]. It is also important that nitinol is a chemical compound; this entails a sharp dependence of its properties on the composition, which, as a rule, cannot be guaranteed more accurately than $0.2 \%$. Most metal implants are made from Co-Cr-Mo and Ti-6Al-4V alloys. But there are problems associated with the effectiveness of these implants. One of them is a higher modulus of elasticity of alloys (more than $100 \mathrm{GPa}$ ) compared with human bone (about 4-30 GPa) [16-17].

A nickel-free $\mathrm{Ti}-\mathrm{Nb}-\mathrm{Ta}$ shape alloy will be promising for the creation of new-generation implants with an extended service life in the human body, improved mechanicalcorrosion properties, and the absence of a negative biological response of the body to the introduction of foreign material. The introduction of alloying elements ( $\mathrm{Nb}$ and $\mathrm{Ta}$ ) into titanium will improve the strength characteristics, lower the elastic modulus, and increase biocompatibility and corrosion resistance [18-19].

In this work corrosion resistance of nonnickel titanium shape memory alloy $\mathrm{Ti}-20 \mathrm{Nb}-$ $10 \mathrm{Ta}$ in an initial state, after volume thermal (annealing) and surface mechanical treatment was defined.

\footnotetext{
${ }^{*}$ E-mail: nacakina@mail.ru

${ }^{\dagger}$ E-mail: mik-z@mail.ru
} 


\section{Materials and methods}

By the method of five-time electric arc remelting with a non-consumable electrode in an argon atmosphere, ingots of these alloys weighing 60 grams were obtained from the starting materials (high purity iodide titanium, tantalum and niobium). After smelting, the ingots were subjected to homogenizing annealing for 12 hours at a temperature of $900^{\circ} \mathrm{C}$ in a vacuum of 10-5 millimeters of mercury.

After homogenizing annealing, the ingots were rolled in streams to sizes of $10 \times 10 \mathrm{~mm}$ at temperatures up to $600^{\circ} \mathrm{C}$. Next, the workpiece was subjected to rotational forging to a diameter of $2-1.8 \mathrm{~mm}$ at temperatures up to $600^{\circ} \mathrm{C}$ and drawn to a diameter of 280 microns at a temperature of $150-200^{\circ} \mathrm{C}$. The dies were heated to $400^{\circ} \mathrm{C}$. Aquadag was used as a lubricant.

After receiving a wire of $280 \mu \mathrm{m}$, annealing was carried out at temperature $800^{\circ} \mathrm{C}$ for 60 minutes in a vacuum of $10-5$ millimeters of mercury.

To investigate the wire microstructure, the preliminary etching of the surface was carried out in a mixture of $1 \mathrm{~mL} \mathrm{HF}+2 \mathrm{~mL} \mathrm{HNO}_{3}$ $+47 \mathrm{~mL} \mathrm{H}_{2} \mathrm{O}$ composition for $2-3 \mathrm{~min}$, upon termination of which the sample was washed several times in distilled water and dried in air. Investigations were carried out on an Axiovert 40 MAT optical metallographic microscope (Carl Zeiss, Germany) with digital image processing. To determine the phase composition, we used an Ultima IV X-ray diffractometer (Rigaku Co., Japan) in $\mathrm{Cu} \mathrm{K} \alpha$-radiation on the basis of BraggBrentano method. Phase analysis was prepared in the PDXL program complex using the ICDD database. The surface morphology and the layerby-layer composition were investigated on a scanning election microscope (SEM) VEGA II SBU with the module INCA Energy for energydispersive analysis (TESCAN, Czech Republic) and on a JAMP 9500F Auger spectrometer (JEOL Co., Japan) in combination with ion etching at argon bombardment under an angle of $30^{\circ}$.
For research of corrosion resistance in this work was decided to pick up and prepare the solutions which acidity would match with acidity of physiological liquids. Since in a human body $\mathrm{pH}$ changes almost from 1 to 9 (for example, 1.531.67 norm of gastric juice; $3.8-4$ in wall area of intestines; 7.34-7.43 norm of blood; $8.5-9$ in a large intestine, etc.), it was decided to carry out tests at several values of $\mathrm{pH}$.

Thus the sour environment of a stomach and intestines is created by solutions of hydrochloric acid of low concentration which in vitro (in case of corrosion of metal samples) are very difficult for reproducing at the set level. Therefore for reproduction of these sour environments and the alkaline environment of the bottom departments of intestines the corresponding standard buffer solutions with $\mathrm{pH} 1.68,3.56,4.01$ and 9.18 were picked up, and for receiving of the neutral environment of plasma of blood and tissues 0.9 weight \% sodium chloride solution (physical solution) with pH 7.39 was used (table 1). Research was conducted on wire samples of equal length with a diameter of 280 microns with total mass of $32.6 \mathrm{mg}$ per $100 \mathrm{ml}$ of buffer solution. The analysis of probes was carried out on sequential atomic-issue spectrometer with induction plasma.

\section{Results and discussion}

As can be seen from the X-ray data (Figure 1 ), the peaks from the elements overlap each other, which makes their identification difficult. After annealing, there is a slight narrowing of the peaks, which indicates stress relief. New phases are not allocated. The alloy is a substitution solution with a b-Ti lattice.

Photos of the microstructure of the $4 \mathrm{~mm}$ diameter bars of Ti-20Nb-10Ta alloy after rotary forging were shown in Figure 2. The microstructure images of the wire after drawing were shown in Figure 3. Plastic deformation of ingots and rods passed with heating and annealing up to $600^{\circ} \mathrm{C}$ in air, but grain boundaries were not etched in microstructural analysis, which 
A. G. Kolmakov, E. O. Nasakina, M. A. Sevostyanov, S. V. Konushkin, K. V. Sergiyenko, and

M. L. Kheifetz

Table 1: Structure and acidity of buffer solutions.

\begin{tabular}{|l|l|}
\hline $\mathrm{pH}$ & Structure \\
\hline 1.68 & Potassium tetraoksalat $\left(\mathrm{KH}_{3} \mathrm{C}_{4} \mathrm{O}_{8} \times 2 \mathrm{H}_{2} \mathrm{O}\right), 0.05 \mathrm{M}$ \\
\hline 3.56 & Potassium acid tartrate $\left(\mathrm{C}_{4} \mathrm{H}_{5} \mathrm{O}_{6} \mathrm{~K}\right), 0.025 \mathrm{M}$ \\
\hline 4.01 & Potassium acid phthalate $\left(\mathrm{C}_{8} \mathrm{H}_{5} \mathrm{O}_{4}\right), 0.05 \mathrm{M}$ \\
\hline 7.39 & Sodium chloride $(\mathrm{NaCl}), 0.9 \mathrm{wt} \%$ \\
\hline 9.18 & Sodium tetraborate $\left(\mathrm{Na}_{2} \mathrm{~B}_{4} \mathrm{O}_{7} \times 10 \mathrm{H}_{2} \mathrm{O}\right), 0.05 \mathrm{M}$ \\
\hline
\end{tabular}

indicated that there was no recrystallization in alloys of all compositions [20]. Thus, as a result of plastic deformation, it is possible to obtain a wire with a nanostructure. This can be determined by transmission electron microscopy during subsequent studies.

The morphology of the Ti-20Nb-10Ta alloy wire surface was shown in Figure 4. High roughness and heterogeneity were noted. It was of interest to study the structure of the surface in regions that differed from each other and at the same time regularly repeated. After surface treatment, its uniformity increased.

Research of corrosion resistance in this work meant definition: 1) whether alloy exposed to interaction with the liquid environment (in any parameters imitating physiological liquids) in which it is; 2) what impact on this interaction character of this medium (structure or acidity) and treatment of sample (mechanical, thermal, structural) renders. Samples of three types were used: initial (sample 1), it after volume thermal (sample 2) and surface mechanical (sample 3) treatment.

Mechanical treatment was made for the purpose of increase of corrosion resistance of alloy due to improvement of quality of a surface: removals from it of pollution, reduction of roughness and, therefore, the total area of the surface treated to action of hostile environment, etc. Thermal - for giving to a material of an optimum set of mechanical properties.

Measurements of elements concentration in studied solutions were made in $5,10,15,20$ and 25 days from the experiment beginning (i.e. entering of samples into solutions). Results of measurements are summarized in table 2 ( $\operatorname{sign}-$ designates concentration less than $0.0066 \mathrm{mg} / \mathrm{l}$ ).

In table 2 results of research of all samples in solution with $\mathrm{pH} 9.18,3.56$ and 4.01 are not given as in these cases it was not observed of an release of metals in solutions for all time of research. Therefore further we will consider behavior only of samples 1, 2 and 3 in solutions with acidity 1,68 and 7,39 . In a neutral solution, only the annealed sample corrodes.

Table 2 demonstrates that insignificant corrosion in solution with acidity 1.68 is observed, that the release of niobium and tantalum ions was not detected in all solutions, regardless of the type of sample, that concentration of titanium ions increases over time, however its relative increase decreases (etching of metals from a surface decreases). This regularity remains in all studied solutions in case of all three samples. In literary data when considering shape memory titanium alloys corrosion a mention of an release of titanium wasn't found. In case of buffer organic sour salts dissolution of the titanium explainable by occurrence of chemical interaction. The example of possible interaction of ions of nickel and titanium with potassium tetraoxalate is given below:

$2 \mathrm{KHC}_{2} \mathrm{O}_{4}+\mathrm{Me}^{2+}+\mathrm{O}^{2-}=\mathrm{K}_{2}\left[\mathrm{Me}^{2+}\left(\mathrm{C}_{2} \mathrm{O}_{4}\right)_{2}\right]+\mathrm{H}_{2} \mathrm{O}$.

Thus it is possible to assume that present at solution oxalic acid acts as a reducer in relation to titanium dioxide of $\mathrm{TiO}_{2}$ average structure making a protective layer (nonstehiometrical oxide film with the presence of $\mathrm{Ti}^{+3}$ ions) of grains and sample as a whole: 


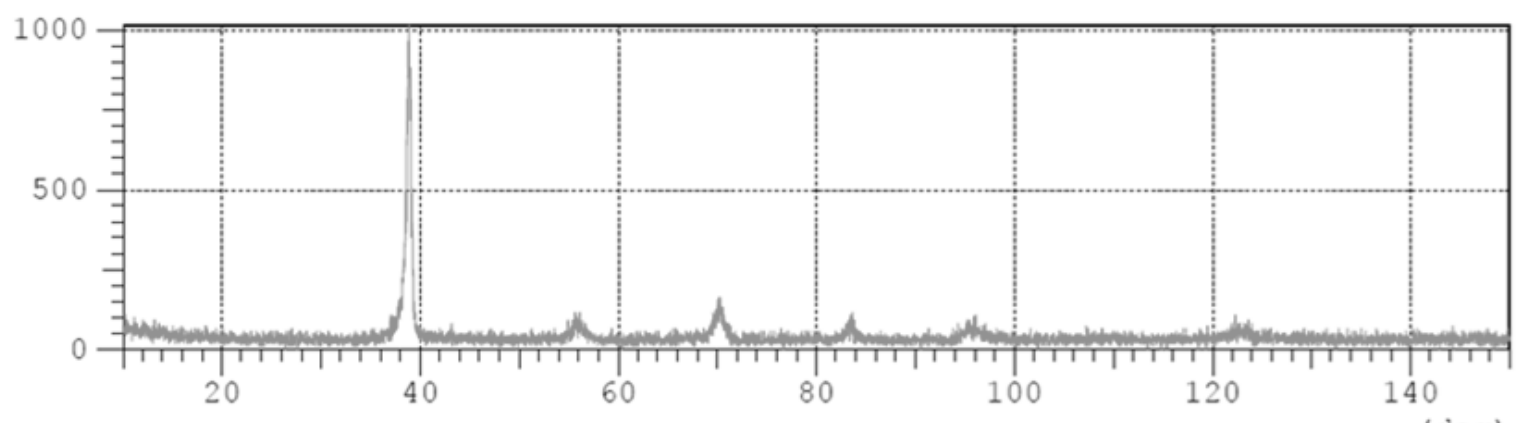

(deg)

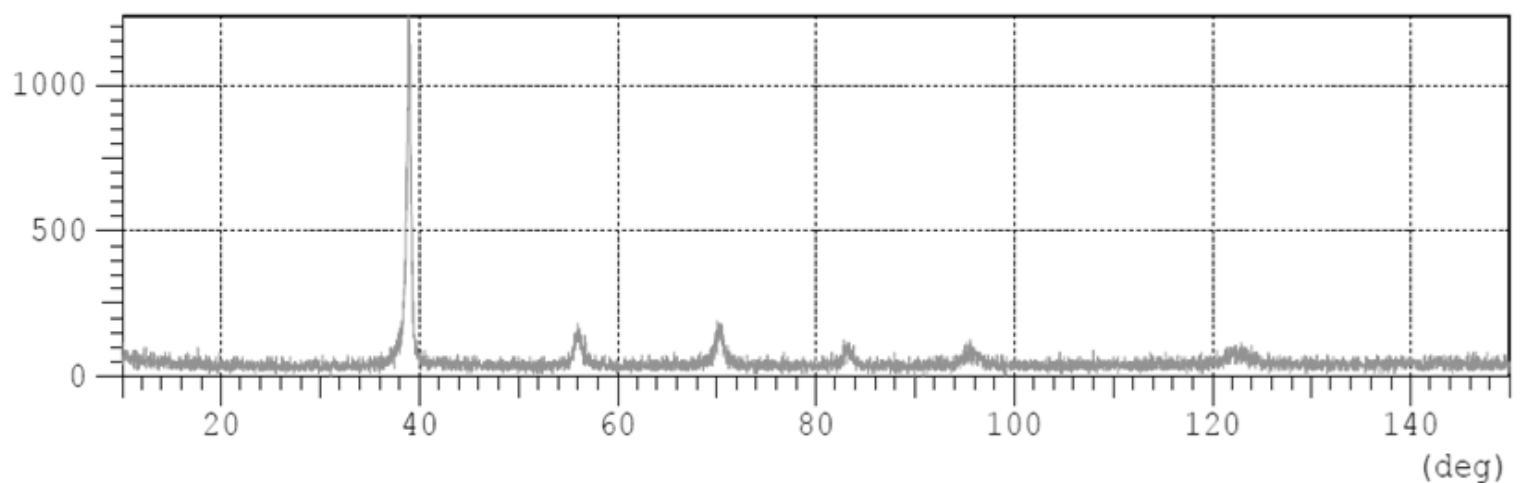

FIG. 1: X-ray data of Ti-20Nb-10Ta alloy before (upper) and after annealing (lower).
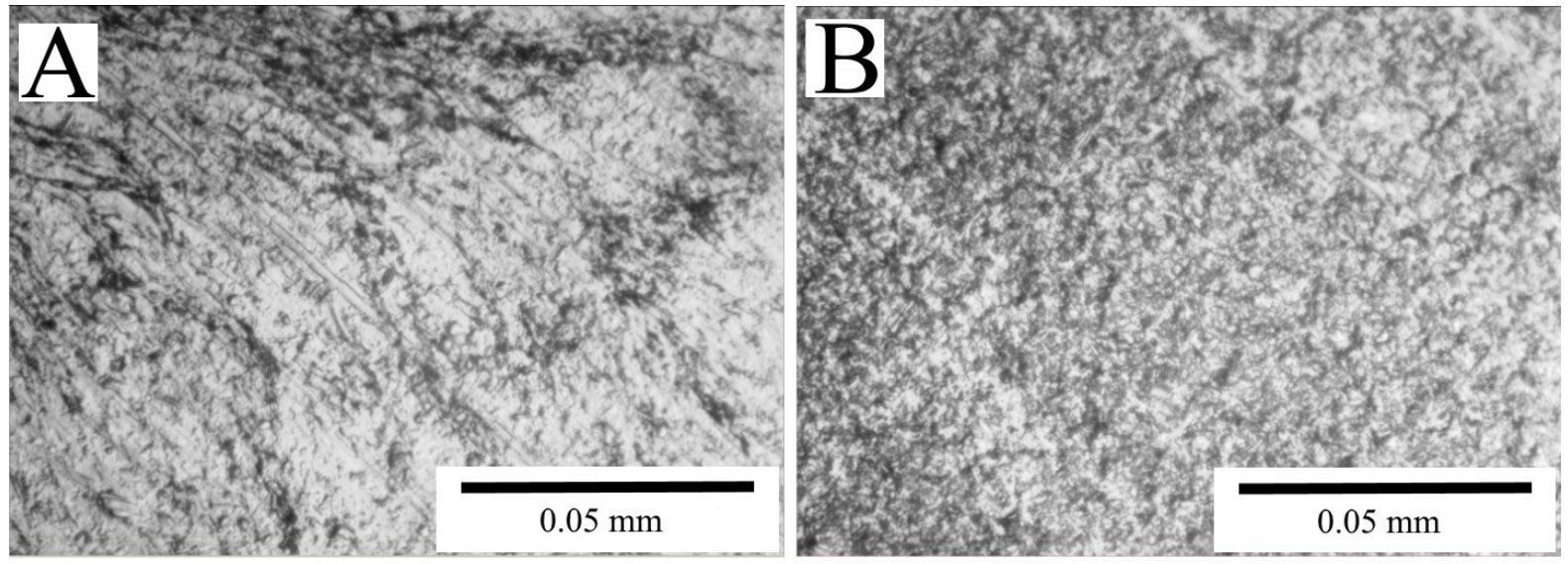

FIG. 2. Microstructure of bars with a diameter of $4 \mathrm{~mm}$ : a) Ti-20Nb-10Ta alloy, cross-section; b) alloy Ti-20Nb$10 \mathrm{Ta}$, longitudinal section.

$$
\mathrm{H}_{2} \mathrm{C}_{2} \mathrm{O}_{4}+\mathrm{TiO}_{2}=\mathrm{TiO}+\mathrm{H}_{2} \mathrm{O}+2 \mathrm{CO}_{2}\left(2 \mathrm{C}^{+3}+\mathrm{Ti}^{+4}=\mathrm{Ti}^{+2}+2 \mathrm{C}^{+4}\right) .
$$

All used acidic organic salts form complexes with refractory metals such as titanium, niobium 
A. G. Kolmakov, E. O. Nasakina, M. A. Sevostyanov, S. V. Konushkin, K. V. Sergiyenko, and 358 M. L. Kheifetz

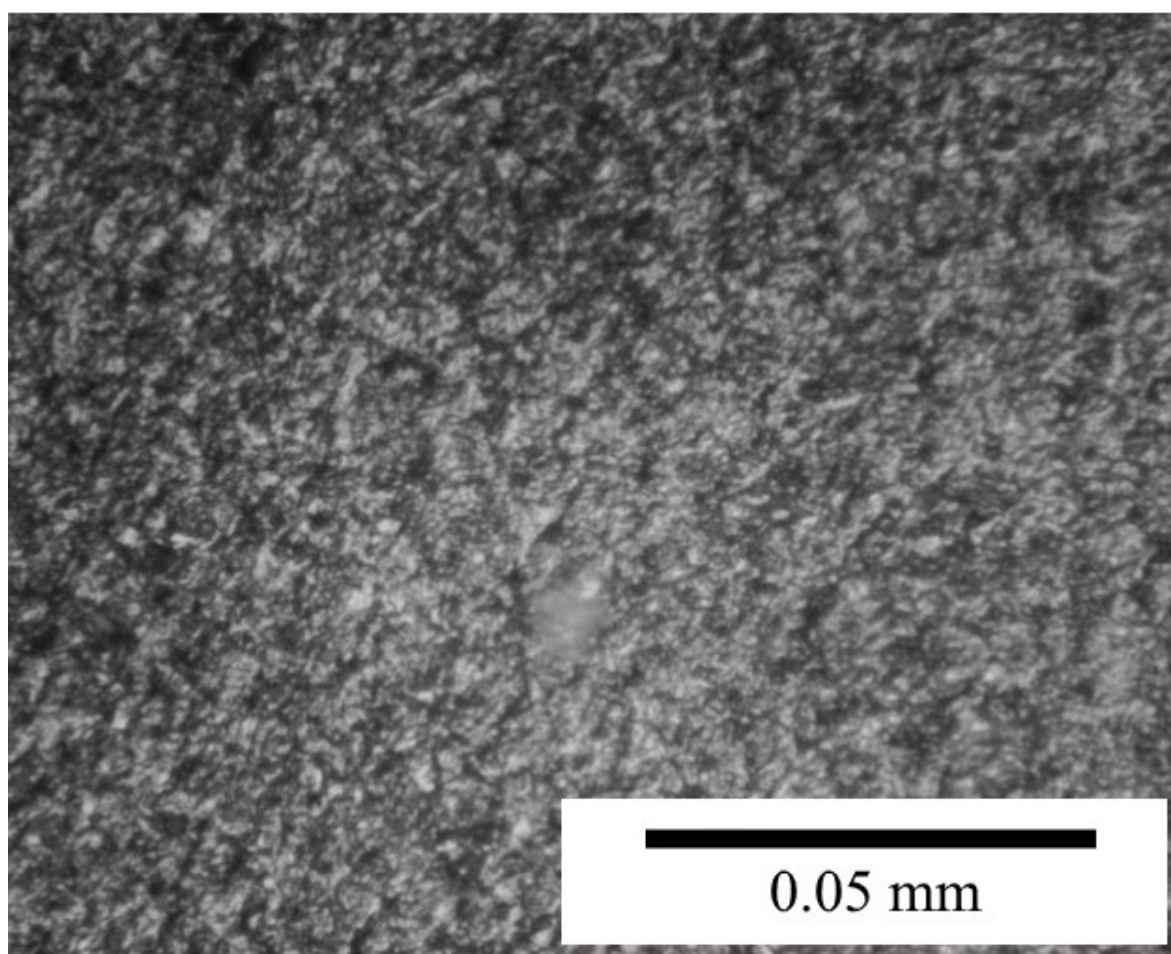

FIG. 3: Microstructure of Ti-20Nb-10Ta alloy wire after drawing.

Table 2: Results of research of corrosion resistance.

\begin{tabular}{|c|c|c|c|c|c|c|c|c|c|c|}
\hline \multirow[t]{3}{*}{$\mathrm{pH}$} & \multirow[t]{3}{*}{$\begin{array}{l}\text { Time, } \\
\text { days }\end{array}$} & \multicolumn{9}{|c|}{ Concentration of an element in solution, $\mathrm{mg} / \mathrm{l}$} \\
\hline & & \multicolumn{3}{|c|}{ Sample 1} & \multicolumn{3}{|c|}{ Sample 2} & \multicolumn{3}{|c|}{ Sample 3} \\
\hline & & $\mathrm{Ti}$ & $\mathrm{Nb}$ & $\mathrm{Ta}$ & $\mathrm{Ti}$ & $\mathrm{Nb}$ & $\mathrm{Ta}$ & $\mathrm{Ti}$ & $\mathrm{Nb}$ & $\mathrm{Ta}$ \\
\hline 1.68 & 5 & 0.910 & - & - & 2.062 & - & - & 0.256 & - & - \\
\hline & 10 & 1.301 & - & - & 4.000 & - & - & 0.470 & - & - \\
\hline & 15 & 1.568 & - & - & 4.703 & - & - & 0.578 & - & - \\
\hline & 20 & 1.751 & - & - & 5.550 & - & - & 0.611 & - & - \\
\hline & 25 & 1.900 & - & - & 6.001 & - & - & 0.660 & - & - \\
\hline 7.39 & 5 & - & - & - & 0.011 & - & - & - & - & - \\
\hline & 10 & - & - & - & 0.014 & - & - & - & - & - \\
\hline & 15 & - & - & - & 0.027 & - & - & - & - & - \\
\hline & 20 & - & - & - & 0.043 & - & - & - & - & - \\
\hline & 25 & - & - & - & 0.050 & - & - & - & - & - \\
\hline
\end{tabular}

and tantalum. It can be assumed that the corrosion process is identical for all metals, regardless of the acidic environment, but the ion release is below the detection limit.

When comparing influence of a processing type on corrosion resistance of samples it is very noticeable that samples after annealing are most subject to corrosion, and surface mechanical treatment strongly increases corrosion resistance of initial nitinol (as expected). Undesirable influence of heat treatment on corrosion resistance can be explained by occurrence of processes of 


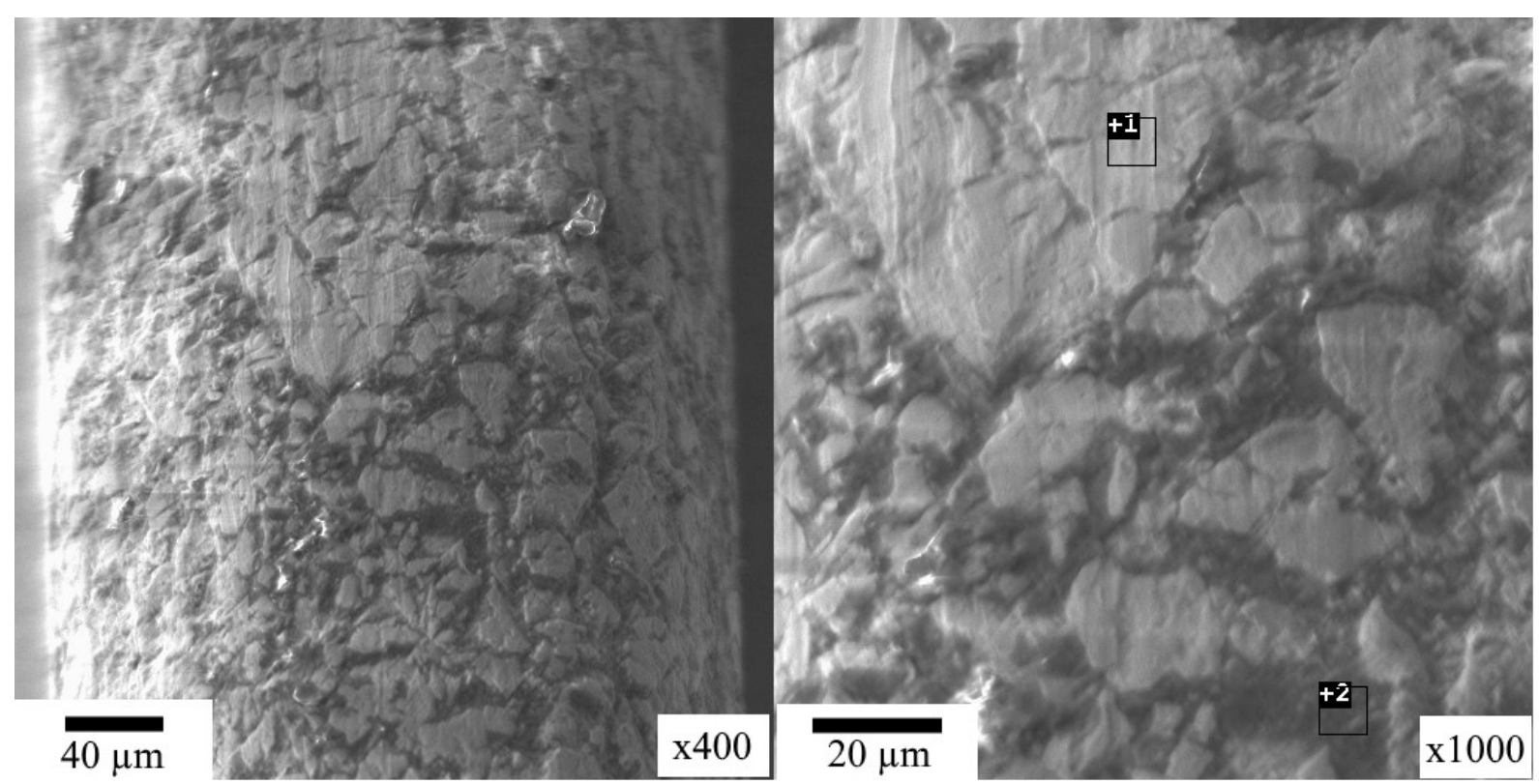

FIG. 4: Morphology of the wire surface.

recrystallization of the external cold-hardened (strengthening) layer on a surface of initial nitinol formed during its receiving. According to literature the heat treatment necessary for stabilization of mechanical properties at a temperature from 400 to $1000^{\circ} \mathrm{C}$ always leads to considerable deterioration of corrosion resistance [13-15]. Regularity remains in all environments.

Corrosion of sample of the same type considerably increases with increase of solution acidity except for physical solution with $\mathrm{pH}$ about 7.39. It meets expectations. On the one hand, the release of metals ions increases in process of acidity increase that in the theory corresponds to increase of "acid"concentration, i.e. aggression of the environment. On the other hand, the high release of metals (it is more, than at solutions with acidity 4.01 and 3.56 ) shows physical solution rather concentrated source of chlorine ions.

Chloride ions, as known, are the ions activators of corrosion providing depassivating, pitting formation action. Corrosion destruction of this type happens at chromic and the chromicnickel alloys, aluminum and its alloys, nickel, zirconium, titanium in environments in which along with a passivator - an oxidizer (including the dissolved oxygen) activating anions $(\mathrm{Cl}$, more $\mathrm{Br}$ and $\mathrm{F}$, etc.) are present, for example, in $\mathrm{NaCl}$ solutions, in sea water, in solutions of chloric iron, at mixes of hydrochloric and nitric acids, etc.

At the same time the titanium is considered well resistant in the oxidizing environments containing ions of chlorine. Value of potential of pitting formation in $0.1 \mathrm{M} \mathrm{NaCl}$ at $25^{\circ} \mathrm{C}$ is $\mathrm{Ti}+12.0 \mathrm{~V}$. Therefore unexpected there was a presence at solution of titanium ions at such large number.

Here it is possible to suggest that it is connected with nanostructure of alloy: nanodimensional grains on a surface when metals leaching from it collapse and also let out in solution large amount of titanium. And though titanium isn't considered as "harmful"to human body also in quantities much exceeding received, it is possible nevertheless to note that the nanostructure has double impact on corrosion resistance of alloy. 
A. G. Kolmakov, E. O. Nasakina, M. A. Sevostyanov, S. V. Konushkin, K. V. Sergiyenko, and

\section{Conclusion}

The methodology for producing homogeneous ingots of the selected composition was developed, including a fivefold electric arc remelting in an argon atmosphere and homogenizing annealing at a temperature of $900^{\circ} \mathrm{C}$ for $12 \mathrm{~h}$ in vacuum.

The technology was developed and wires with a diameter of 280 microns from the selected alloy were obtained. The technology includes the rolling of smelted ingots, rotational forging of billets and drawing of bars at temperatures up to $600^{\circ} \mathrm{C}$ in air.

Mechanical treatment allows to increase its corrosion resistance by $2-3$ times. Regularities of corrosion changing depending on acidity and composition of solutions meet expectations (the greatest concentration of metals is observed in solution with $\mathrm{pH} 1.68$, slightly smaller in physical solution).

In solution with $\mathrm{pH} 9.18,3.56$ and 4.01 was not observed of an release of metals for all time of research. In a neutral solution, only the annealed sample corrodes. The release of niobium and tantalum ions was not detected in all solutions, regardless of the type of sample.

\section{Acknowledgments}

The work was supported by the Ministry of Science and Higher Education of the Russian Federation (grant identifier RFMEFI60419X0242).

\section{References}

[1] S. Shabalovskaya. On the nature of the biocompatibility and medical applications of NiTi shape memory and superelastic alloys. BioMedical Materials and Engineering. 6, 267-289 (1996).

[2] D. Stoeckel. Nitinol medical devices and implants. Minimally invasive therapy \& allied technologies. 9, 81-88 (2000).

[3] K. Takamura, K. Hayashi, N. Ishinishi, T. Yamada, Y. Sugioka. Evaluation of carcinogenicity and chronic toxicity associated with orthopedic implants in mice. Journal of Biomedical Materials Research. 28, 583-589 (1994).

[4] M. Uo, F. Watari, A. Yokoyama, H. Matsuno, T. Kawasaki. Dissolution of nickel and tissue response observed by X-ray scanning analytical microscopy. Biomaterials. 20, 747-755 (1999).

[5] J. Wataha, N. O'Dell, B. Singh, M. Ghazi, G. Whitford, P. Lockwood. Relating nickel-induced tissue inflammation to Ni release in vivo. Journal of Biomedical Materials Research. 58, 537-544 (2001).

[6] D.J. Wever, A.G. Veldhuizen, J. de Vries, H.J. Busscher, D.R.A. Uges, J.R. van Horn.
Electrochemical and surface characterization of a nickel-titanium alloy. Biomaterials 19, 761-769 (1998).

[7] S.A. Shabalovskaya, He Tian, J.W. Anderegg, D.U. Schryvers, W.U. Carroll, J. Van Humbeeck. The infuence of surface oxides on the distribution and release of nickel from Nitinol wires. Biomaterials. 30, 468-477 (2009)

[8] T. Hu, C. Chu, Y. Xin, S. Wu, K.W.K. Yeung, P.K. Chu. Corrosion products and mechanism on NiTi shape memory alloy in physiological environment. Journal of Materials Research. 25, 350-358 (2010).

[9] C. Trepanier, R. Venugopalan, R. Messer, J. Zimmerman, A.R. Pelton. Effect of passivation treatments on nickel release from Nitinol. In: Society for Biomaterials: 6th World Biomaterials Congress Transactions (Honolulu, May 15 - 20 2000). (Society for Biomaterials, Minneapolis, 2000). P. 1043.

[10] R.D. Barrett, S.E. Bishara, J.K. Quinn. Biodegradation of orthodontic appliances: part I, biodegradation of nickel and chromium in vitro. American Journal of Orthodontics and Dentofacial Orthopedics. 103, 8-14 (1993). 
[11] S. Tomić, R. Rudolf, M. Bruncko, I. Anẑel, V. Savić, M. Ćolić. Response of monocytederived dendritic cells to rapidly solidified nickeltitanium ribbons with shape memory properties. European cells and materials. 23, 58-81 (2012).

[12] J. Ryhanen, E. Niemi, W. Serlo, E. Niemela, P. Sandvik, H. Pernu, T. Salo. Biocompatibility of nickel-titanium shape-memory metal and its corrosion behavior in human cell cultures. Journal of Biomedical Materials Research. 35, 451-457 (1997).

[13] C. Trepanier, M. Tabizian, L.H. Yahia, L. Bilodeau, D.L. Piron. Effect of modification of oxide layer on NiTi stent corrosion resistance. Journal of biomedical materials research. 43, 433- 440 (1998).

[14] C. Trepanier, J. Fino, L. Zhu, A.R. Pelton. Corrosion resistance of oxidized Nitinol. In: Proceedings of SMST-2003, Monterey. (Monterey, CA, 2004). Pp. 267-276.

[15] L. Zhu, C. Trepanier, J. Fino, A.R. Pelton. Oxidation of Nitinol and Its Effect on Corrosion Resistance. In: ASM Materials\& Processes for Medical Device Conference (Anaheim, 8-10 September 2003). (ASM International, Materials
Park, Cleveland, : P. 156-161 (2004).

[16] Geetha M, Singh A K, Asokamani R., Gogia A. K. Ti based biomaterials, the ultimate choice for orthopaedic implants a review 2009 Progress in Materials Science 54, P. 397-425 DOI: 10.1016/j.pmatsci.2008.06.004

[17] Kaur M, Singh K. Review on titanium and titanium based alloys as biomaterials for orthopaedic applications 2019 Mater Sci Eng: C 102, P. 844-862. doi.org/10.1016/j.msec.2019.04.064

[18] M. Niinomi. Titanium Alloys. In: Encyclopedia of Biomedical Engineering. Ed.-in-Chief R. Narayan. (Elsevier, Amsterdam, 2019). Pp. 213224.

[19] Kaur Manmeet, K. Singh. Review on titanium and titanium based alloys as biomaterials for orthopaedic applications. Mater Sci Eng. C 102, 844-862 (2019).

[20] S.M. Dubinskiy, S.D. Prokoshkin, V. Brailovski et al. Structure formation during thermomechanical processing of $\mathrm{Ti}-\mathrm{Nb}-\mathrm{Zr}(\mathrm{Ta})$ alloys and manifestation of the shape-memory effect. Phys. Met. Metallogr. 112, 529-542 (2011). 